\title{
Environmental Product Declarations for plants and soils: how to quantify carbon uptake in landscape design and construction?
}

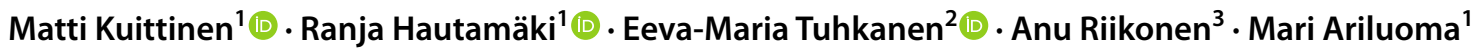

Received: 4 November 2020 / Accepted: 10 May 2021 / Published online: 8 June 2021

(c) The Author(s) 2021

\begin{abstract}
Purpose Currently, no clear guidance exists for ISO and EN standards of calculating, verifying, and reporting the climate impacts of plants, mulches, and soils used in landscape design and construction. In order to optimise the potential of ecosystem services in the mitigation of greenhouse gas emissions in the built environment, we unequivocally propose their inclusion when assessing sustainability.

Methods We analysed the life cycle phases of plants, soils, and mulches from the viewpoint of compiling standard-based Environmental Product Declarations. In comparison to other construction products, the differences of both mass and carbon flows were identified in these products.

Results Living and organic products of green infrastructure require an LCA approach of their own. Most importantly, if conventional life cycle guidance for Environmental Product Declarations were to be followed, over time, the asymmetric mass and carbon flows would lead to skewed conclusions. Moreover, the ability of plants to reproduce raises additional questions for allocating environmental impacts.

Conclusions We present a set of recommendations that are required for compiling Environmental Product Declarations for the studied products of green infrastructure. In order to enable the quantification of the climate change mitigation potential of these products, it is essential that work for further development of LCA guidance be mandated.
\end{abstract}

Keywords Environmental Product Declaration · Carbon · Landscape design · Plant · Soil $\cdot$ Mulch $\cdot$ Life cycle assessment

\section{Introduction}

\subsection{The importance of carbon uptake in the built environment}

Mitigating the progressing climate crises requires enhancing both natural and technological carbon (C) sinks. Anthropogenic greenhouse gas (GHG) emissions have grown close to 2400 gigatons of carbon dioxide equivalents $\left(\mathrm{GtCO}_{2} \mathrm{e}\right)$ between 1850 and 2019. From this emission, the

Communicated by Adriana Del Borghi.

Matti Kuittinen

matti.kuittinen@aalto.fi

1 Department of Architecture, Aalto University, PO Box 31000, 00076 Aalto, Finland

2 Natural Resources Institute Finland, Helsinki, Finland

3 Department of Forest Sciences, University of Helsinki, Helsinki, Finland natural sinks of our planet have absorbed approximately $2280 \mathrm{GtCO}_{2} \mathrm{e}$, leaving an imbalance of emissions and sinks around $120 \mathrm{Gt}$ of $\mathrm{CO}_{2} \mathrm{e}$ (Friedlingstein et al. 2019). The Intergovernmental Panel on Climate Change (IPCC) has estimated that the remaining quota of emissions before their radiative forcing causes a global average warming beyond 1.5 degrees, which is approximately $570 \mathrm{GtCO}_{2} \mathrm{e}$ (IPCC 2018).

However, our current emission trends are widening the gap between the emissions and climate goal towards 35 GtCO2e by 2030 (UNEP 2019). In particular, the production of key construction materials-cement, steel, aluminium, and plastics-will potentially cause $920 \mathrm{GtCO}_{2} \mathrm{e}$ emissions if the current trends were to continue (Material Economics 2018). When demand-side sectors are scrutunised, the built environment is often claimed to cause around one third of society's GHG emissions (ECORYS 2014).

In theory, it would be possible to enhance $\mathrm{C}$ uptake and storage in the built environment through biobased products, $\mathrm{CO}_{2}$ hardened concrete (Sanna et al. 2014), or $\mathrm{CO}_{2}$-based 
plastics (Cui et al. 2019). Furthermore, emerging negative emission technologies (NETs), such as artificial photosynthesis or building-integrated direct air capture of $\mathrm{CO}_{2}$, could be useful, but only after having matured (Dittmeyer et al. 2019). Currently, it appears unrealistic to expect the NETs to result in notable emissions reductions in less than 20 years (McGlashan et al. 2012). While waiting for these technologies to mature, there is a need for instant increases of $\mathrm{C}$ uptake and safe storage.

Natural ecosystem services remain a low-cost option, which have not yet been deployed for their full potential for $\mathrm{C}$ uptake in the built environment (Dhakal 2010). The main natural GHG sinks consist of terrestrial sinks (forests and soils) that currently remove approximately $12.8 \mathrm{GtCO}_{2} \mathrm{e} / \mathrm{a}$, and ocean sinks that remove approximately $9.5 \mathrm{GtCO}_{2} \mathrm{e} / \mathrm{a}$ (Friedlingstein et al. 2019). For successful mitigation of anthropogenic emissions, 0.9 billion hectares (ha) of new forests would be required (Bastin et al. 2019); however, there are competing land-use needs for agriculture and urbanisation (Bringezu et al. 2014; Li et al. 2019). As these changes in land-use impact the potential of ecosystems to sequester $\mathrm{C}$ from the atmosphere, strategies are urgently required for guarding and enhancing the land-system related $\mathrm{C}$ sinks, including in the built-up areas.

In the urban environment, multiple ecosystem services are produced by the green infrastructure (GI), consisting of plant and soil systems both within built and natural areas. In addition, the climate change mitigation benefits of green infrastructures include an energy-saving potential in terms of the insulation and cooling effects of vegetation and green structures. For example, Regner et al. (2014) suggest that to reach low or even neutral climate impacts, both onsite renewable energy technology and extensive building-integrated vegetation are required. Despite its multiple co-benefits and potential for mitigating GHG emissions, GI has remained largely unexamined in the sustainability assessments of the built environment.

\subsection{Missing environmental information and needs in landscape design and construction}

Although life cycle assessment (LCA) has not been widely applied to the climate impacts of GI, it would be a valuable tool for estimating and comparing the long-term environmental performance of different urban green space projects (Strohbach et al. 2012). The C-regulating capacity of different GI elements greatly depends on certain elements, including the potential biomass of the plant (larger plants such as trees which possess a larger $\mathrm{C}$ storage), the amount of $\mathrm{C}$ that is released during construction and maintenance phases, as well as the decomposition of biomass (Setälä et al. 2016; Linden et al. 2020). The relevance of different GI solutions for achieving climate neutrality in a wider context of built environment has started to increase (Kuittinen et al. 2016, 2021), and city-wide estimates of urban carbon pools are becoming available (Richter et al. 2020).

The C-regulating capacity of GI can be supported at all stages of urban development, from strategic regional planning to detailed landscape design, construction, management, and maintenance. In general, the landscape architectural design process is divided into four main stages: the preparation phase, concept design, developed design, and technical design, which are followed by construction and maintenance (RIBA 2013). The first phase addresses project objectives, sustainability aspirations, and budget, in addition to the required site information and landscape analyses. In the following phase, a concept design is produced by considering various features, for example, circulation, vegetation, water design, and management. In the developed design, the concept is elaborated, which is followed by the technical design on hard and soft detailing, specifications, and tender documents for construction. While a concept and developed design phases define the spatial organization and type of green elements, a more detailed technical plan includes specific information on environmental products, such as trees, shrubs, and other vegetation, in addition to growing media.

After the design process, the construction phase also involves several decisions on the carbon capacity of GI, including procurement of materials, such as plants and growing media, as well as implementation of earthworks and planting. In the maintenance phase, the key decisions on GI concern maintenance techniques, in addition to the use of mulches, fertilisation, and irrigation. Thus, several decisions on the $\mathrm{C}$ capacity of GI are reached during the landscape design and construction process. However, the long-term environmental performance of GI is not systematically integrated in the process, nor quantified as an entity due to a lack of tools and missing environmental information (Säynäjoki 2015; Strohbach et al. 2012).

In order to grasp the $\mathrm{C}$ uptake potential of GI, comparable and quantifiable product information would be required at different stages of the design process and for its key stakeholders. These include, in addition to the designers, municipal authorities, clients, and project developers, as well as consumers and users of the green spaces, for whom information regarding the sustainable use of public funds for GI would be relevant. However, sustainability metrics or LCA tools on GI are scarce and no uniform standards exist. For example, the Environmental Product Declarations (EPDs) that are available for most construction products have not been developed for GI products. EPDs contain quantitative information on GHG emissions and other environmental properties that help the designers to compare and select products that are optimal for their project (see Sect. 2.2). However, there is no EPD information for plants, soils, or mulches. 
Moreover, EN standards for a sustainability assessment of building products or buildings appear to lead into a need to include GI in the assessment. For example, standard EN 15,978 defines that "the object of assessment is the building and its site" (CEN 2011b). Standard EN 15804 states that "the total of neglected input flows per module... shall be a maximum of 5\% of energy usage and mass" (CEN 2019). Thus, one could assume that GI within the site should be taken into account in sustainability assessments. Still, standards do not seem to offer instructions for considering the organic components of the GI. This may well be the reason for several LCA studies on typical applications of GI choosing to include construction products but omitt plants, soils, and mulches (Kosareo and Ries 2007; Bianchini and Hewage 2012; Chenani et al. 2015; Brudler 2016; Koura et al. 2020).

Sustainability schemes, such as LEED, BREEAM, DGNB, SITES, or Level(s), do not appear to offer sufficient information for quantifying the $\mathrm{C}$ uptake potential of plants, soils, and mulches (see Table 1). Some of these certification schemes allow credits if EPDs are used for the assessed project-yet EPDs are not available for plants, soils, mulches, or growing media. One of the emerging tools for supporting GI in private properties is the green factor method, which is gradually establishing itself in many cities around the world (e.g. Keeley 2011; Juhola 2018). The green factor method requires that a certain number of green elements be implemented in property development. Thus, the tool can potentially increase green biomass on sites, although it focuses on other benefits of green, and does not specifically address $\mathrm{C}$ storage.

Agricultural products are to a certain extent similar to organic products used in GI. LCA is commonly used for agricultural products and tools exist for assessing their impacts from "cradle to farm gate" (Renouf et al. 2018). In many agricultural LCA studies, the system boundaries have been drawn around the agricultural phase (including e.g. field or greenhouse operations for producing the crop), production phase (including steps for producing and packaging the end-product), distribution phase, use phase (i.e. consumption), and finally, the waste and by-product treatment in the end-of-life (see e.g. Arzouanidi et al. 2017). However, the plants that produce the agricultural products are often present in the agricultural phase without their life cycle impacts being assessed, indicating these methods are not well suited to plant products used in landscaping.

To sum up, limited knowledge on mitigating GHG emissions, applicable to practice, is available on the level of designing, constructing and maintaining a park or a courtyard. To be able to plan for sequestering $\mathrm{C}$ on a project level, information on GHG emissions and C storage of GI products would be essential.

\subsection{The aim and scope of this paper}

The aim of this paper is to evaluate the match between the key sustainability standards to the environmental assessment of plants and soils as well as to simultaneously ascertain if there is a need for further clarification. The scope of this article is on a product level in a landscape design and construction project, excluding the urban planning phase. We present a schematic framework for an assessment of plants, soils, and organic environmental products that are part of the design palette of a landscape architect or designer of green infrastructure. We do not address the design of the site of the building, although studies on the level of a site, neighbourhood, or an area would also be valuable.

The background for this article was presented in Sect. 1. In Sect. 2, we summarise the standard-based process of sustainability assessment of building products as well as the key processes for $\mathrm{C}$ uptake and storage for plants and soils. Section 3 analyses the match of the current standardbased LCA methods to the sustainability assessment of plants and soils. Suggestions are presented in Sect. 4 to account for the potential of plants, soils, and mulches in $\mathrm{C}$ uptake and storage within the built environment. Section 5 summarises our conclusions and suggestions for further research.

\section{Methods}

\subsection{Materials and methods of this study}

This study was carried out in a multi-professional team that possessed both scientific and practical experience of sustainability assessment, landscape architecture, ecosystem services of GI, horticulture, soil sciences, and climate policies. First, relevant LCA standards (EN and ISO) were reviewed for their applicability to our scope. Then, we conducted a literature survey on LCAs performed on GI products or structures, as well as collected information on the latest research findings and established practices for quantifying $\mathrm{C}$ flows of plants, soils, and mulches. Thereafter, our findings were mirrored against the typical GI design and construction process as well as practice on landscape design. Finally, we summarised our findings utilising the framework of LCA provided in EN standard suite 15643 (CEN 2010), standard EN 15804 (CEN 2019), and EN 15978 (CEN 2011b).

This section presents the typically utilised methodology for compiling EPDs for construction products. We also summarise the existing assessment methods for quantifying the $\mathrm{C}$ flows for plants, soils, and mulches. 


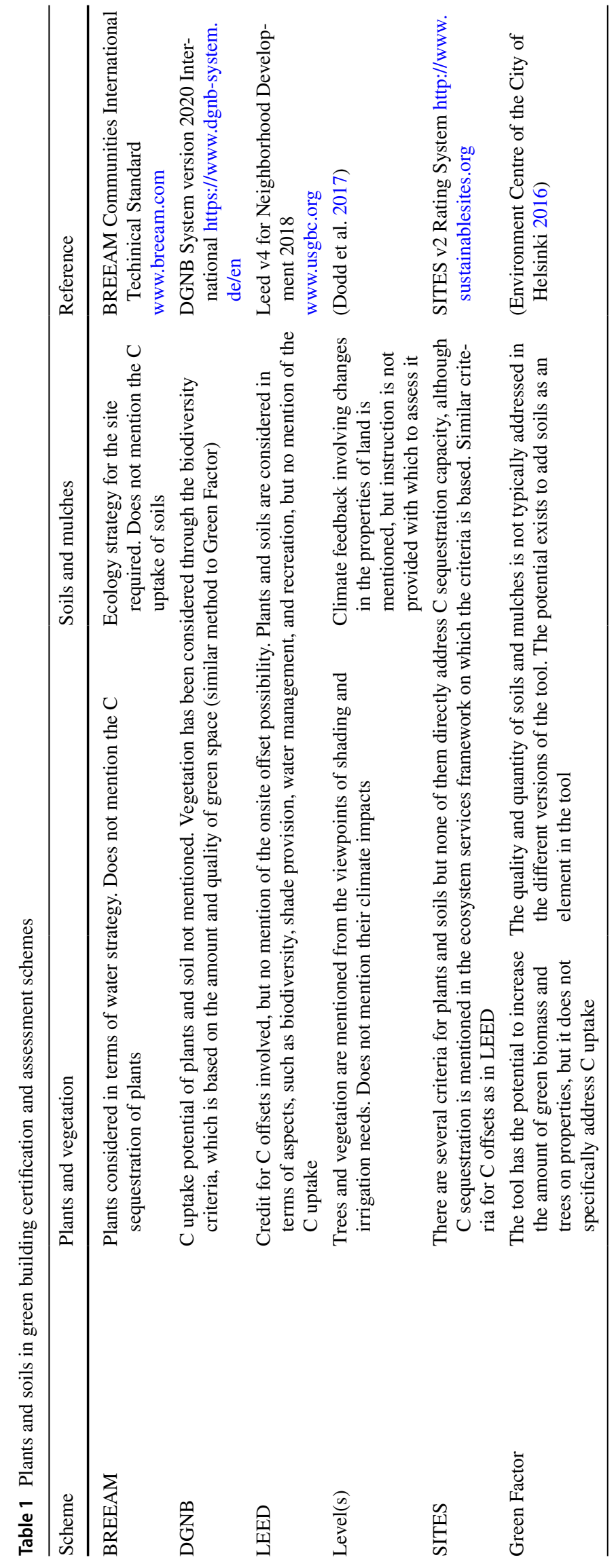




\subsection{The methodology for compiling Environmental Product Declarations for construction products}

Standard ISO 14025 (ISO 2010) defines the types of different ecolabels, of which EPDs are listed as "type III ecolabels." Their compilation is guided by respective EN and ISO standards with an independent third party verifying the results. Currently, EPDs only cover construction products. Due to our construction product-focused and standard-based approach, we have not included the methodology of Product Environmental Footprint (PEF) (European Commission, Joint Research Centre 2012) in our paper, although it might offer insight into the life cycle impacts of many agricultural (consumer) products.

The methodology for compiling EPDs is laid out in Standard EN 15804. The underlying method is processbased, attributional life cycle assessment (LCA). International standard suite ISO 14040 and the standards developed by CEN's technical committee TC 350 form the basis for building and building product LCA. The life cycle of a building or a building product is divided into four main modules and further divided into 17 submodules, as presented in Table 2.

As there are several different building product groups, it would be difficult to include all their specialties into one standard. Therefore, several Product Category Rules (PCRs) have been developed based on the core standard EN 15804. Furthermore, national PCRs have been created to allow the local conditions to be considered in EPDs.

The process of compiling an EPD starts usually from the need to have sustainability information for the needs of a

Table 2 Life cycle stages and modules according to Standard EN 15643-2 (CEN 2011a)

\begin{tabular}{lll}
\hline Production stage & A1 & Raw material extraction \\
& A2 & Transport to factory \\
A3 & Manufacturing \\
Construction stage & A4 & Transport to site \\
Use stage & A5 & Construction work \\
& B1 & Use of product in building \\
& B2 & Maintenance \\
& B3 & Repair \\
& B4 & Replacement \\
& B5 & Refurbishment \\
& B6 & Operational energy use \\
& B7 & Operational water use \\
Cnd-of-life stage & C1 & Demolition work \\
& C3 & Transport \\
& C4 & Faste management disposal \\
Additional information & D & Benefits and loads beyond \\
& & the system boundary \\
\hline
\end{tabular}

specific market or user group. After the scope and goal have been defined, all processes that are associated with the production process are documented as well as their input and output flows recorded. Thereafter, the calculation of impacts for these flows is carried out according to selected and required methods for characterisation, allocation, weighting, categorisation, grouping, and normalisation. Finally, the results are documented in a standardised format. An external inspector verifies the EPD results prior to their publication.

\subsection{Existing assessment methods for the carbon storage and sequestration of urban trees}

In the photosynthetic process, green plants bind atmospheric $\mathrm{CO}_{2}$ and water with the energy of sunlight resulting in the production of sugars and oxygen. Sugars are further converted into various organic compounds for the growth and metabolism of plants. In woody species (trees, shrubs), organic $\mathrm{C}$ is stored in leaves, twigs, roots, and trunks. A part of the fixed $\mathrm{C}$ is allocated via roots to mycorrhizal fungi or as root exudates directly to the soil (Grayston et al. 1997). This $\mathrm{C}$ and decomposing dead parts of the plants (fine roots, leaf, twig, and bark litter) contribute to soil organic $\mathrm{C}$ stock.

$\mathrm{C}$ is bound to wood as organic compounds such as cellulose and lignin. When modelling the $\mathrm{C}$ stock of trees, the widely employed estimate of the wood dry mass $\mathrm{C}$ content is 50\% (Chow 1989), although detailed measurements from different parts of trees reveal a $\mathrm{C}$ content range from 0.42 to $0.61 \mathrm{kgC} / \mathrm{kg}$ (Thomas and Martin 2012). Depending on the life cycle of the tree and on the use of the wood material after the tree removal, wood may contribute as a long-term C stock.

For urban trees and urban forests, $\mathrm{C}$ storage and annual $\mathrm{C}$ sequestration can be modelled using i-Tree software (USDA Forest Service et al. 2020). The i-Tree software is developed for estimating the quantity and economic value of some ecosystem services provided by urban trees, including $\mathrm{C}$ storage and sequestration, air pollutant binding, storm water attenuation, production of volatile organic compounds (VOC), and effects on building energy use. The tool is peer-reviewed and originally based on Urban Forest Effects model (UFORE) (Nowak et al. 2008). It has been applied in 130 countries, mostly in North America, but also in Europe (Raum 2019).

For $\mathrm{C}$ storage, above-ground and below-ground woody parts of trees are considered (Nowak et al. 2008). C storage calculation is based on the biomass of each tree, which is calculated using the trunk diameter at breast height (DBH) and the height of the tree. The needles of conifers are calculated in $\mathrm{C}$ storage, whereas the leaves of broad-leaved species are not.

Annual gross $\mathrm{C}$ sequestration is calculated considering the estimated annual growth rate of (DBH), the location and its frost-free period, tree condition, and light availability. 
The net $\mathrm{C}$ sequestration is calculated by subtracting the estimated release of $\mathrm{C}$ via rapid (e.g. mulching, burning) or slower processes (e.g. decomposition) from the gross $\mathrm{C}$ sequestration. The proportion of $\mathrm{C}$ released via these processes is estimated based on the land use category. In park areas, it is assumed that $50 \%$ of the dead trees are left to decompose at the site, while in vacant land, the assumption is $100 \%$ (Nowak and Crane 2002).

For modelling $\mathrm{C}$ storage and sequestration, the data of individual trees is needed, in addition to weather data. City tree databases, collected for management and planning purposes, can be used as source data for modelling. i-Tree is a practical tool for studying the current state of urban trees in a limited area or in a city, and can be used to follow up the development of the tree population as well as the ecosystem services that they provide. The i-Tree Planting tool can be used to forecast the ecosystem services in the future, such as the $\mathrm{C}$ storage of the trees that are planted now. Currently, this tool is usable only in Northern America; therefore, the applicability of i-Tree to the planning phase in other continents is still limited.

In the forestry sector, there are several advanced models (EFDM, EFISCEN, FORMIT, MELA, MONSU, and PREBAS) for calculating the $\mathrm{C}$ sink of a forest ecosystem as a yearly change in the $\mathrm{C}$ storage of trees and soil (Kalliokoski et al. 2019). The variables used in these models include field data on the forest at starting point, the growth models of trees, targets for the amounts of logging and type of silvicultural practices, as well as an option to include different climate scenarios.

\subsection{Existing assessment methods for the carbon storage and uptake of shrubs and herbaceous plants}

C-binding capacity as well as the $\mathrm{C}$ content of shrub and herbaceous species are remarkably smaller than that of trees because of their smaller biomass and leaf area. The $\mathrm{C}$ storage of a plant can be estimated by measuring (or modelling) the total dry biomass of the different plant organs (leaves, stems, roots, reproductive organs), and by multiplying it with the average $\mathrm{C}$ content of the organ (Ma et al. 2017). Biomass can be assessed by destructive sampling or by modelling (e.g. by i-Tree).

Biomass measurement and $\mathrm{C}$ content assessments for above-ground plant parts are easier to perform than for underground parts, which have been studied less. In practice, the underground $\mathrm{C}$ stocks of plants are typically included in soil $\mathrm{C}$ stocks due to methodological difficulties in separating living roots from various soil organic matter components. For woody species, root biomass is commonly estimated to be $27 \%$ of aboveground biomass (Atsbha 2019). For agricultural crops, an agroecosystem model (Crop-DNDC) integrates detailed crop growth algorithms with an existing soil biogeochemical model and simulates $\mathrm{C}$, nitrogen, and water cycles in agroecosystems with a relatively complete scope (Zhang et al. 2002; Li et al. 1992). The estimates of residential lawn $\mathrm{C}$ storage range from $3 \mathrm{tCO}_{2} / \mathrm{ha} / \mathrm{a}$ (Raciti et al. 2011) to $11 \mathrm{tCO}_{2} / \mathrm{ha} / \mathrm{a}$ (Vasenev and Kuzyakov 2018), although the $\mathrm{C}$ is mostly stored in the soil, not in the plants.

Net photosynthetic rate as $\mathrm{CO}_{2}$ uptake per unit leaf area $\left(\mu \mathrm{mol} \mathrm{CO} \mathrm{CO}_{2} / \mathrm{m}^{2} / \mathrm{s}\right)$ can be measured using a portable infrared meter, and such data exist on a variety of plant species and conditions. Net photosynthesis per unit leaf area varies depending on particular aspects, such as plant condition, available light, drought stress, and temperature. However, net $\mathrm{C}$ sequestration capacity is approximately dependent on the total leaf area of the plant. Estimation of the total leaf area of a plant can be based on features such as the biomass of leaves. The ratio of leaf area to leaf biomass is available for several species in experimental research, although it must be remembered that the ratio is affected by environmental conditions, such as the availability of light.

In i-Tree Eco, the leaf area and leaf biomass of a shrub are estimated based on the volume of the shrub, which is calculated from the average height and ground area covered by the shrub.

\subsection{Existing assessment methods for the carbon stocks and uptake of soils}

In some regions, most urban plantings are planted on manufactured planting soils, which are used to improve the quality of soil to meet the demands of desired plants. As planting soils form a considerable mass of GI, their sustainability information would similarly benefit the climate targets of landscape design.

Stocks of soil organic carbon (SOC) in urban green areas originate from planting soil raw materials, local vegetation, and litter, or, for example, from organic mulching materials. Especially peat and composts are raw materials of importance in terms of product LCA. In soil, organic materials are constantly decomposed by soil fauna and flora, and SOC content at any given time is determined by the balance of organic material input and breakdown mainly into $\mathrm{CO}_{2}$. This process can also produce GHGs with a higher climate impact than $\mathrm{CO}_{2}$, such as methane and dinitrous oxide. To form an overall understanding of the climate effects of a planting soil, these are of importance especially during the use stage of the product life cycle.

Planting soil raw materials are typically mineral soil (sands and sandy loams of varying origin) and peat, either alone or combined with compost. More rarely, other components, such as biochar, can be used as a source of SOC. The environmental impacts of using peat in energy production are fairly well documented in literature (IPCC 2006), but the 
applicability of these estimates when peat is used in planting soil has raised some issues (Riikonen et al. 2017). In energy production, it is assumed that all $\mathrm{C}$ bound in peat is lost to the atmosphere, but when peat is mixed with soil, $\mathrm{C}$ loss is likely to be slower and less complete.

The environmental effects of producing compost from various biogenic, organic waste materials, such as garden and kitchen waste, have been studied to some extent (Lim et al. 2016; Saer et al. 2013). These depend on and vary based on various agents, such as the raw materials, processes and process conditions, and bulking materials; therefore, in practice, they must be assessed case by case. This may result in the overall climate impact of a compost product proving to be either positive or negative. When assessing planting soil LCA, it would be sensible to include the GHG effects of the composting process involved in the raw materials of manufacturing.

Measurement methods for SOC stocks and sequestration are well developed for e.g. agricultural and forest soils. Amongst other applications, these methods are used to estimate $\mathrm{C}$ emissions and sequestration for the LULUCF sector. The methods are predominantly based on measuring $\mathrm{C}$ in soil samples as well as for developing soil $\mathrm{C}$ dynamics models based on measured soil $\mathrm{C}$ stocks and the share of $\mathrm{C}$ fractions with different decomposition rates.

It is a relatively simple and established method to measure soil $\mathrm{C}$ stocks from samples by combining information from dry combustion and bulk density measurements (e.g. Pouyat et al. 2006). Any uncertainties in area-based soil C stocks are predominantly related to sampling, especially its representativeness in terms of spatial variability and soil depth (Bae and Ryu 2015).

Assessment methods for soil $\mathrm{C}$ uptake are usually modelbased on a large scale (e.g.Liski et al. 2006; Trammell et al. 2017). The models require input information on variables, such as soil C quality, vegetation, and climate. Based on these variables, they can assess $\mathrm{C}$ sequestration in soil. For urban environments, validated models are not currently available, and tests with models parameterised in other environments have not shown great promise (Qian et al. 2003; Trammell et al. 2017; Rasinmäki and Känkänen 2014).

A currently available method for assessing soil $\mathrm{C}$ uptake on a more modest spatial scale is sequential soil sampling and stock measurement; a change in stock being potentially interpreted as $\mathrm{C}$ uptake or emission. However, it is more laborious and less universally applicable. Ideally, these sequential measurements are combined with measurements of other C and GHG fluxes, for example, methane and dinitrous oxide emissions as well as dissolved $\mathrm{C}$ leaching from the same area. The methods for these measurements are quite well known from long-term ecosystem studies and measuring platforms, such as SMEAR or LTSER (e.g. Hari et al. 2013; Sier and Monteith 2016), but such stations in urban environments are still rare. Whereas $\mathrm{C}$ stock changes can be attained with more simple measurements, by also measuring $\mathrm{C}$ fluxes and other greenhouse gases, such as dissolved organic $\mathrm{C}, \mathrm{CO}_{2}, \mathrm{CH}_{3}$, and $\mathrm{N}_{2} \mathrm{O}$ emissions, a more comprehensive picture might emerge of the overall climate impacts involved in the $\mathrm{C}$ sequestration measured.

\subsection{Mulches and other organic products}

In addition to being decorative, mulches have important practical functions: they prevent weeds, reduce evaporation, and protect from solar radiation. Mulch can form naturally or can be produced from several organic materials. These include both natural materials (e.g. chipped branches and bark) and, in some cases, recycled bio-based products (e.g. chipped timber or bamboo).

We could not identify any methods for estimating the environmental impacts of mulches. Measurement of the $\mathrm{C}$ content, release or uptake of mulches is greatly dependent on their raw material. The $\mathrm{C}$ content itself is related to the properties of the biomass. Nonetheless, the release of the biogenic $\mathrm{C}$ during the use of mulches through decomposition process may occur through aerobic or anaerobic decomposition. The latter leads to strong GHG impacts due to methane emissions. To complicate the matter further, mulch $\mathrm{C}$ can be transported downwards in the soil and positively affect soil C stocks (Lindén et al. 2020).

In addition to plants and soils, the process of green infrastructure planning, construction, and maintenance involves several other products, such as stones, fertilisers, protection, and support materials for plants. In addition, green areas contain structures that are made of typical construction products, such as wood, concrete, steel, and plastics. Furthermore, most products involve the use of packaging materials. Although all these products and materials belong to the components of landscape design, most of them resemble more typical construction products. Thus, their environmental benchmarking may follow the principles laid out in respective PCRs.

\section{Results}

Plants and soils behave in a dynamic manner over their life cycle as a product. Therefore, declaring their climate impacts - through the flows of $\mathrm{C}$ and other GHGs-requires adjustments to the process of compiling EPDs. In this section, we present the differences between these products and other construction products in terms of documenting the $\mathrm{C}$ flows within the product system. The results are arranged according to the life cycle stages and the modules of EPDs as presented in Standard EN 15643-2 (CEN 2011a). 


\subsection{Life cycle carbon flows of plants}

Our analysis reveals that when living plants are assessed, the inventory phase of LCA requires further development. A building product leaves the factory gate (module A3) as an intermediate product, ready for use in the building process. Plants, bulbs, or seeds leave the nursery as "infants" that continue to grow once planted. Therefore, the environmental benefits and loads declared on the "factory gate" can only reflect the production of the plantlet, sapling, or seedling, not the fully grown plant. As the inventory in LCA is essentially about tracking material flows, this approach is not applicable for plants.

In contrast, for plants, the environmental impacts are predominantly linked to growing and maintenance conditions (mostly in modules B1-2). Several factors have an impact on the growth of a plant. These include the growth form of the plant and its potential size at maturity, climate, nutrient availability, other abiotic conditions, the specific growing conditions of the site, and maintenance related variability to the growth of a plant—not to mention pests, diseases, and possible vandalism. During their growth, many plants reproduce leading to the need to develop allocation rules of biomass and $\mathrm{C}$ flows of the descendants. Therefore, scenarios for growth and maintenance remain inaccurate, even if the taxa and growth conditions were known.

The end-of-life of a plant is not a punctual phenomenon from the viewpoint of its biomass and biogenic $\mathrm{C}$. Plants drop leaves, bark, twigs, and branches throughout their life, and some of them may renew their biomass several times over their life. Depending on the maintenance and growing site of the plant, this constant flow of biomass may cause either environmental benefits (e.g. accumulation of organic $\mathrm{C}$ into soil) or loads (e.g. release of methane in an anaerobic decomposition). Depending on the plant type and its growing site, its ultimate removal from the site (module $\mathrm{C} 1$ ) may require machinery (e.g. removal of a tree or lawn), manual work (e.g. removal of a bush) or no intervention at all (e.g. seasonal flowers that decompose in the flowerbed). Thus, quantifying the impacts for module $\mathrm{C}$ differs from that of many building products (Fig. 1)

The same applies to the net benefits that can be declared for a building product beyond its life cycle (module D). Plants can seldom be "reused," nor is their biomass usually "recycled" (except wood in some cases). Decomposition of dead plant matter into mulch or compost could theoretically be considered an equivalent to either recycling (that may lead into environmental benefits) or final disposal (which is an environmental burden). This choice will lead to different outcomes.
Table 3 presents the proposal for adjusting the framework of an EPD for the declaration of the $\mathrm{C}$ flows of plants. Figure 2 illustrates the flows of $\mathrm{C}$ across these life cycle stages.

\subsection{Life cycle carbon flows of soils and mulches}

Regarding the life cycle impacts of planting soils, declaration of the environmental performance deviates in several ways from conventional building products. According to our assessment, these include raw material extraction (A1), use (B1), and final disposal (C4).

The raw material for soil products can include materials, such as natural organic or mineral soils and lime originating from limestone, composted organic waste originating from various sources from organic household waste to municipal sewage sludge, and agricultural residues, such as straw. In addition, industrially produced raw materials, such as fertilizers, super adsorbent polymers, or expanded clay aggregates, may be used-usually in relatively small amounts. Depending on the ratio of the raw materials used, the inherent $\mathrm{C}$ content varies, and this content can be reported based on soil sampling. However, the microbes of the soil will impact the decomposition rate of soil organic matter. The amount and taxa of the microbes at given time may be reported if extensive sampling is possible, but are subject to change over time and according to environmental conditions.

The production of mulches is comparable to the production of soils in respect to the inherent $\mathrm{C}$ content. This greatly depends on the raw material mix. If the organic raw material is from a sustainably managed source, biogenic $\mathrm{C}$ neutrality could be claimed according to the principles of EN 16485 which instruct the compilation of EPDs for wood-based construction products.

During the use phase (B1), both soils and organic mulches release $\mathrm{C}$ due to decomposition, but $\mathrm{C}$ also accumulates in soils. Environmental conditions, such as temperature and moisture, as well as flora and fauna of the soil, have a dynamic impact on this, but the effects are only weakly understood, therefore preventing them from being properly accounted for (Riikonen et al. 2017). Furthermore, the vegetation that is planted on the soil has a significant impact on $\mathrm{C}$ accumulation. Thus, the soil $\mathrm{C}$ uptake or release of GHGs is a dynamic process.

At the end-of-life stage, the soils can be reused or left in place, unless their quality has suffered due to issues, such as the presence of contaminants, invasive alien plants, or weeds. The final disposal of soils usually transpires in a landfill site that is meant for soils. It is also likely that most soils (as a growing medium) never reach a similar end-of-life as typical construction products do. Thus, the $\mathrm{C}$ dynamics in soils would continue even if the soil were removed from the site for which it was purchased. 


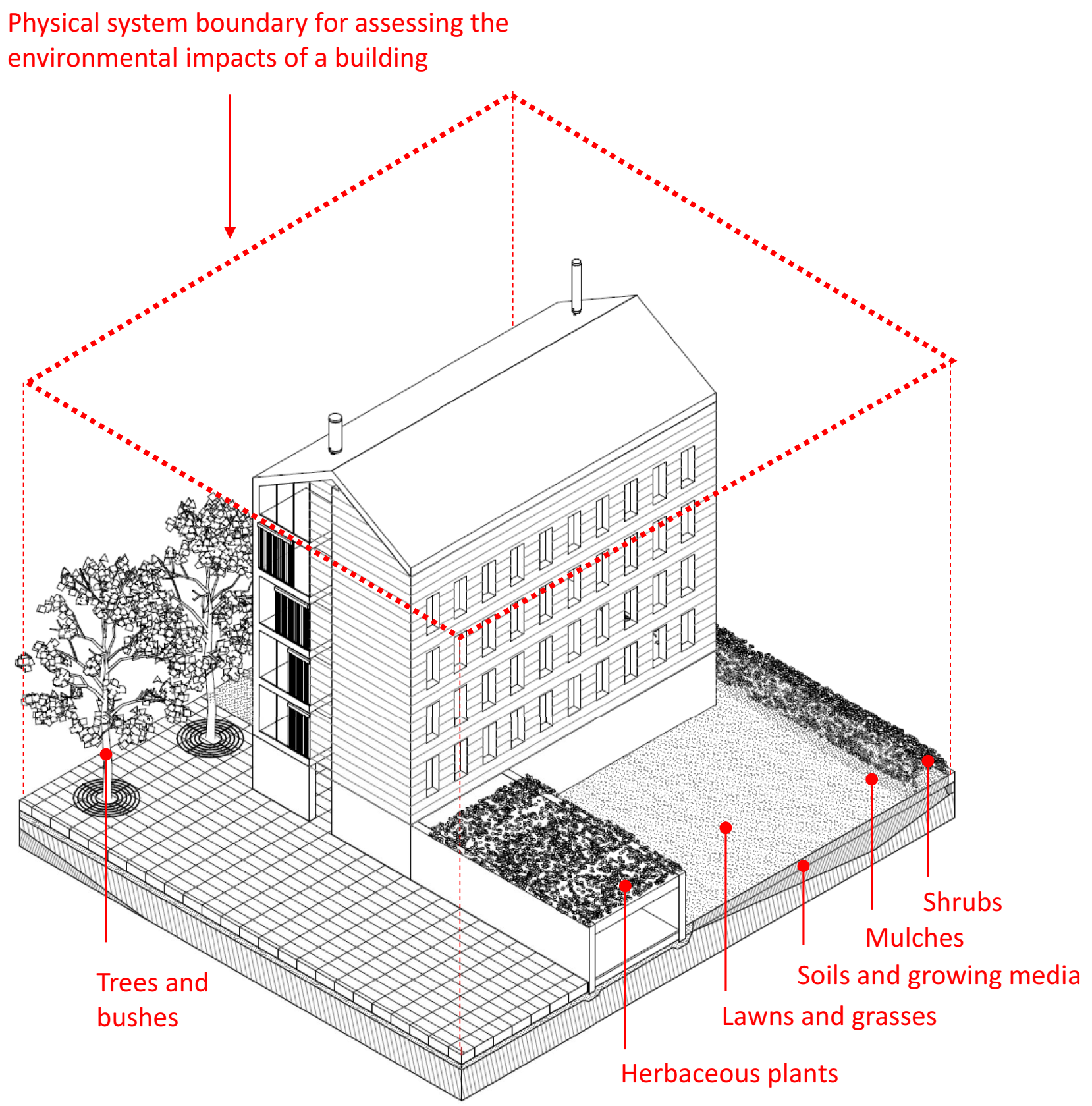

\section{Physical system boundary for assessing the} environmental impacts of a building 
Table 3 Carbon flows of a plant in different life cycle phases

\begin{tabular}{|c|c|c|}
\hline \multicolumn{2}{|c|}{ Life cycle modules } & \multirow{2}{*}{$\begin{array}{l}\text { Differences to a conventional EPD } \\
\text { - Raw materials include seeds, bulbs, or sprouts, as well as ancillary materials and chemicals required for the } \\
\text { nursery. In some cases, the seeds or bulbs are the products }\end{array}$} \\
\hline 1 & Raw material extraction & \\
\hline A2 & Transport to factory & - As in conventional EPDs \\
\hline A3 & Manufacturing & $\begin{array}{l}\text { - In the case of seedlings being the product: Nursing the plants, growing media at the nursery, watering, fertiliz- } \\
\text { ing, applying pest controls } \\
\text { - Environmental information can only be declared for the nursery processes and possible ancillary materials }\end{array}$ \\
\hline A4 & Transport to site & - As in conventional EPDs \\
\hline A5 & Construction work & $\begin{array}{l}\text { - Construction of the planting site requires machinery } \\
\text { - Planting of larger trees may require machinery }\end{array}$ \\
\hline B1 & Use of the product & $\begin{array}{l}\text { - At this stage, most of the } \mathrm{C} \text { uptake happens. A large fraction of the } \mathrm{C} \text { is segregated in the soil and mycorrhizas, } \\
\text { which contribute to the soil } \mathrm{C} \text { stock. } \mathrm{C} \text { is also released through plant respiration and natural decay (net vs. gross } \\
\mathrm{C} \text { uptake) } \\
\text { - Plants release gases and aerosols, which may have consequential effects on the climate (e.g. formation of } \\
\text { clouds) } \\
\text { - Plants reproduce during their use }\end{array}$ \\
\hline B2 & Maintenance & $\begin{array}{l}\text { - Trimming, pruning, cutting, mowing, irrigating, weeding and other such actions, depending on the plant and } \\
\text { plantation }\end{array}$ \\
\hline B3 & Repair & - Not relevant for most plants. Large tree branches are sometimes supported to prevent damage \\
\hline B4 & Replacement & - Relevant on the level of a plantation. Parts of individual plants are not replaced \\
\hline B5 & Refurbishment & - Not relevant for plants. May be relevant for the entire plantation \\
\hline B6 & Operational energy use & $\begin{array}{l}\text { - Not relevant for plants } \\
\text { - Plants may affect the cooling or warming energy consumption of buildings through shading and wind protectio }\end{array}$ \\
\hline B7 & Operational water use & - Not relevant. Water for irrigation included in B1 \\
\hline $\mathrm{C} 1$ & Demolition work & - As in conventional EPDs \\
\hline $\mathrm{C} 2$ & Transport & - As in conventional EPDs \\
\hline $\mathrm{C} 3$ & Waste management & - Organic waste: landfilling prohibited depending on legislation \\
\hline $\mathrm{C} 4$ & Final disposal & - Can be returned to nature after end-of-waste status has been reached \\
\hline $\mathrm{D}$ & $\begin{array}{l}\text { Benefits and loads } \\
\text { beyond the system } \\
\text { boundary }\end{array}$ & $\begin{array}{l}\text { - Reuse unlikely. Recycling into mulch and compost the most likely option, and in this case may replace virgin } \\
\text { soils. Recycling to other bio-based products possible } \\
\text { - Energy recovery or incineration possible }\end{array}$ \\
\hline
\end{tabular}

\section{Discussion}

Based on the results, we conclude that there are several gaps in both the methods and data required for compiling an EPD for plants, soils, and mulches. Some of these are essential and specific to the products of landscape design and construction. In this section, we suggest modifications to account for various life cycle stage effects on GI products, and present the practical implications of the study.

\subsection{The growth and reproduction of plants call for LCA adjustments}

As shown in Sect. 3, the growth of plants differentiates them from conventional construction products. Therefore, it is suggested that LCA methods for plants be developed.

The dynamic $\mathrm{C}$ flows through photosynthesis, accumulation in plant biomass or as soil $\mathrm{C}$ and decomposition of organic matter often considerably alter the $\mathrm{C}$ content of plants. To give any indication of the potential of
C sequestration at this stage, a growth model should be instigated, as well as scenarios for both growth conditions, local weather, and maintenance.

In most cases, most plants (especially woody species) have produced considerably more biomass than was originally planted into the site, resulting in asymmetric mass flows over the life cycle. If the biomass that exits the system boundary is considered to decompose and release GHGs, the GHG balance between module A and module $\mathrm{C}$ is deemed to show environmental burdens for the use of such plants. Thus, one could erroneously surmise that the best solution would be to avoid plants as the GHG release from the decomposition of their increased biomass would be reported to be a climate burden. Moreover, plants drop leaves, needles, and dead biomass over their life cycle. This may enrich the SOC, decompose naturally, or be removed from the site to separate waste management process.

As the growth models are not available for many plant species, we suggest that a general growth model be adapted 


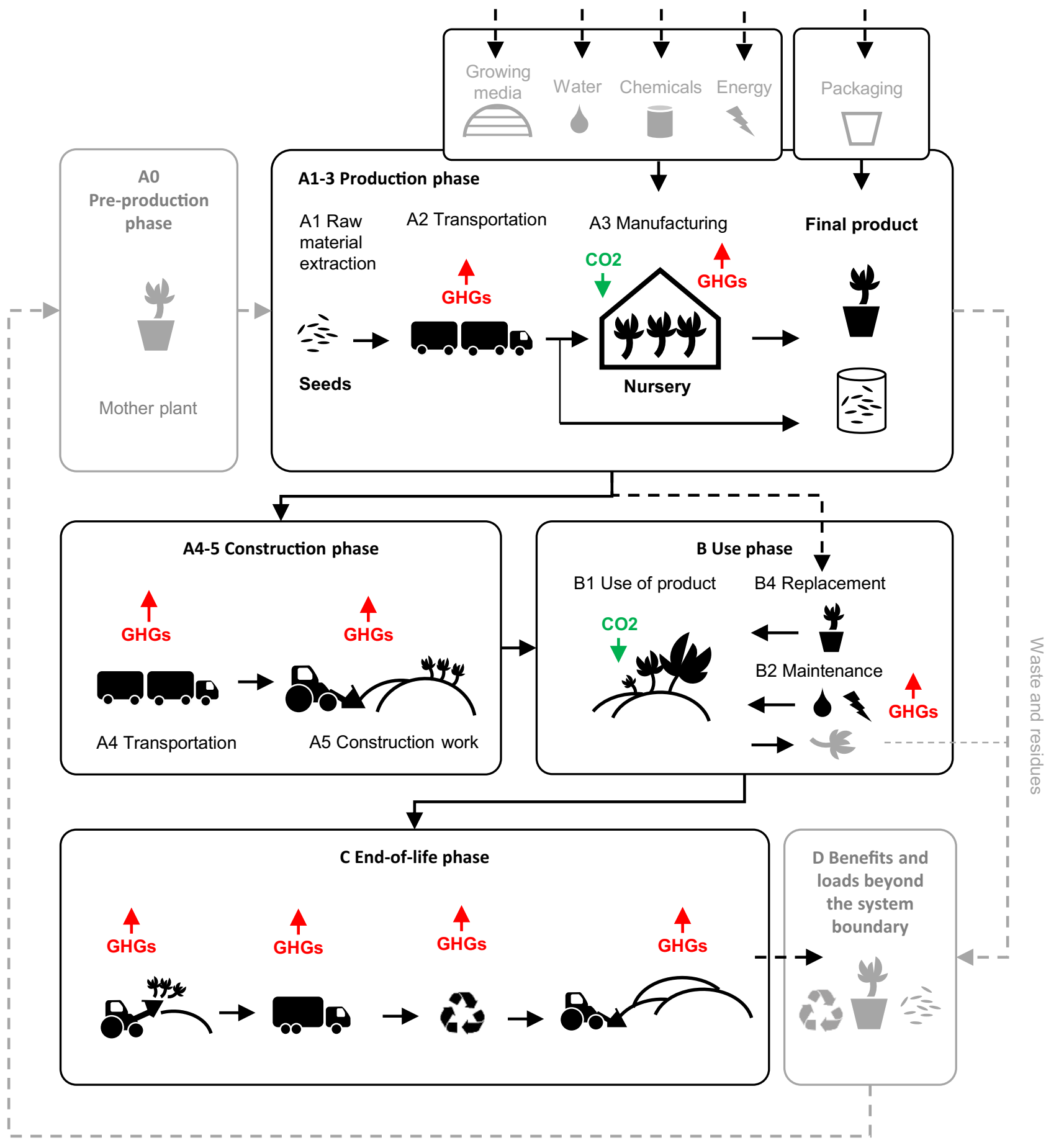

Fig. 2 Simplified system boundaries and flows of carbon during the life cycle of a plant used in landscape construction works

and applied to classes or types of plant based on aspects such as growth habit and final size (e.g. small or big tree species, grass, perennials, and shrubs). The growth model should include both above and below ground biomass of the studied plants. Local weather data is needed in the models to predict the yearly growth rate and accumulation of biomass and C. Furthermore, the effects of changing climate on growth rate via altered temperature and moisture should be included in the models.

Based on the growth model, we suggest declaring mass and biogenic $\mathrm{C}$ contents for plants at different stages of the lifecycle. $\mathrm{C}$ as produced for describing the state in which the plant leaves the nursery, and $\mathrm{C}$ as grown for describing the potential range of biogenic $\mathrm{C}$ content typical for the 


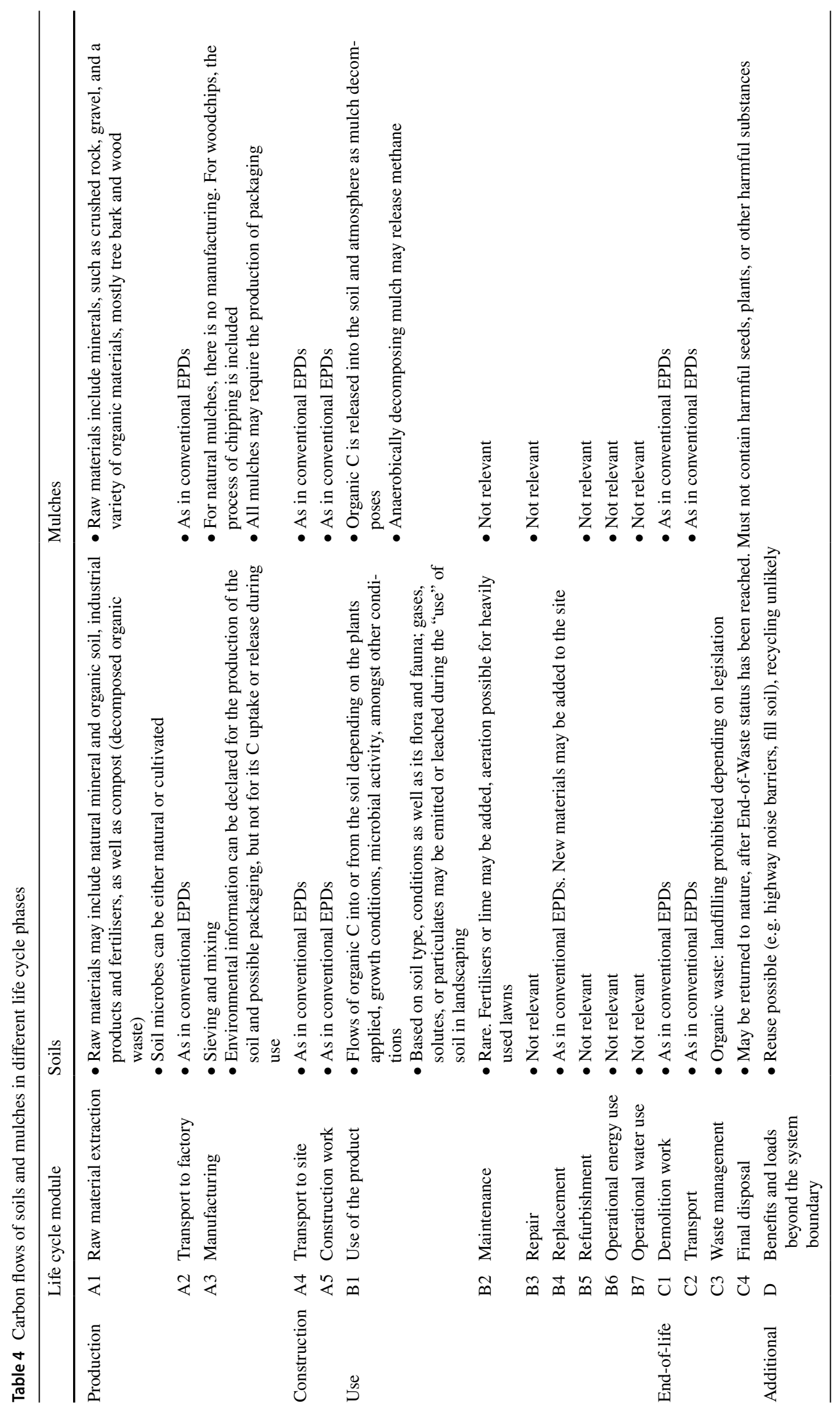




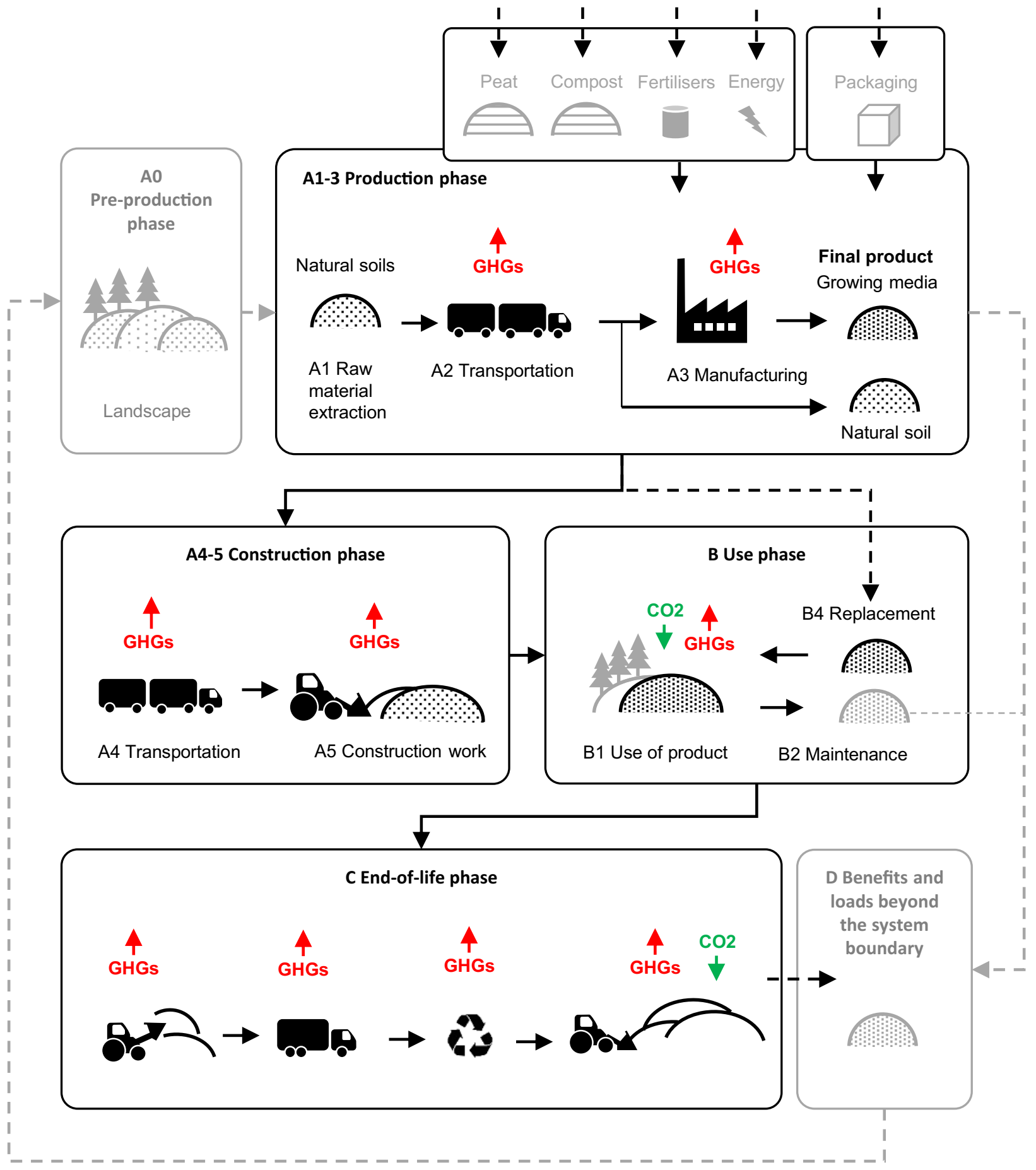

Fig. 3 Simplified system boundaries and flows of carbon during the life cycle of soils used in landscape construction works

plant species in different growth and weather conditions (Fig. 4).

For most herbaceous plants and certain bushes, it appears more practical to report the environmental impacts per area, instead of per single plant, after they have been planted. This is due to their nature of forming dense plantations, in which it is difficult to differentiate between individual plants. Therefore, we suggest that area would be used as the default functional unit in the cases for which plants grow as uniform plantation.

The ability of plants to reproduce (either sexually or asexually) raises an interesting question of allocation. If the $\mathrm{C}$ flows of the seedlings and new plants would be allocated to the originally planted mother plant, this would further increase the asymmetry of the mass flows over the life cycle stages. As the realistic reproduction and growth 


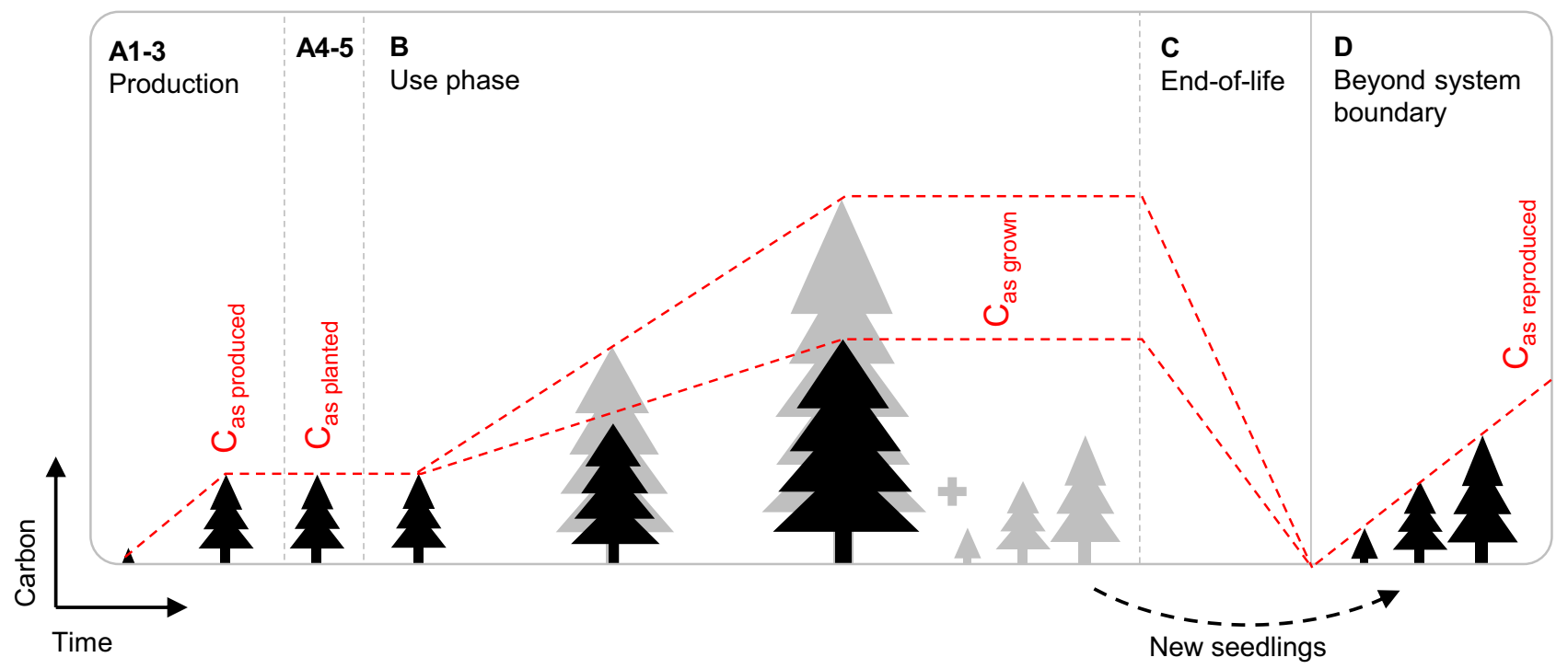

Fig. 4 The accumulation of biomass and carbon into a tree during its growth

of the seedlings depends more on the use conditions than on the studied plant, any scenarios are deemed to be inaccurate. Our suggestion for the question of reproduction is to allocate the resource and $\mathrm{C}$ flows of the descendants into impacts that occur beyond the studied life cycle (i.e. in module D). However, the question regarding scenarios for the reproduced biomass and its growth remains unanswered and requires further studies.

\subsection{The inherent carbon dynamics of soils and mulches require adjustments to LCA rules}

As described earlier, the raw material extraction as well as the end-of-life of soils and mulches require the development of LCA calculation rules and practices.

Mulches may produce benefits that enhance the growth of plants. These could be considered in a consequential LCA. In practice, it is very precariousto predict the exact role of these benefits for a plantation, as numerous factors affect it. Therefore, we suggest that these potential benefits be omitted from the reporting of the environmental properties of mulches.

The natural decomposition of mulches can lead into asymmetric mass and $\mathrm{C}$ flows within a studied system boundary of a product. The product as such typically decomposes in a few years but may contribute to SOC for much longer. From the viewpoint of $\mathrm{C}$ flows, the accumulation of SOC is a consequence of using mulches and $\mathrm{C}$ input of plants in soil. However, as the product has decomposed, it would not appear relevant to allocate the climate impacts of mulch derived SOC to the mulch product. This could be solved by declaring the entire end-of-life phase as irrelevant for mulches. At least, one should avoid double-counting the organic releases of $\mathrm{C}$ in mulches during their use (natural decomposition) and end-of-life (balancing of mass flows).

In addition, soils can have asymmetric flows of mass and $\mathrm{C}$ over their life cycle as a product. As the actual uptake of $\mathrm{C}$ into soils largely depends on the climate and vegetation, we suggest that the $\mathrm{C}$ uptake information would be given as a set of scenarios that consider different plant types and different growth conditions on a given type of growing medium. However, it would not be relevant to declare that enriched SOC would be an environmental burden in the end-of-life phase of a soil product. As the same dilemma also applies to plants, we suggest that the $\mathrm{C}$ content for soils be similarly declared as for plants: $\mathrm{C}$ as produced (content after Module $\mathrm{A} 3$ ) and $\mathrm{C}$ after use (content after use phase, based on representative $\mathrm{C}$ accumulation scenarios).

The $\mathrm{C}$ dynamics of soils continue after they have been removed from the site and disposed of, or reused for another project. In the case of final disposal (module $\mathrm{C} 4$ ), the net benefits arising from the $\mathrm{C}$ dynamics of the soils could be reported as an additional environmental benefit beyond the studied system boundary (module D). However, the further accumulation and/or release of soil $\mathrm{C}$ depends on environmental conditions, such as local vegetation, climate, and depth of deposition in soil. Given this inherent complexity, we propose that scenarios for $\mathrm{C}$ uptake or release outside of the system boundary be given only as an additional technical scenario information, and be excluded from the environmental product information of soils.

As a result of the probably asymmetric mass flows, the question of relevant functional unit in LCA would also require clarification. In the beginning of the product's life cycle, tonnes, cubic metres or even square meters of area 
with certain growth conditions would be relevant. During and especially at the end of the life cycle, tonnes, and cubic metres may be less relevant, because of the $\mathrm{C}$ and mass dynamics of soils. Therefore, using, for example, $1 \mathrm{~m}^{2}$ of area with certain growth conditions as a functional unit could help to rectify this imbalance.

\subsection{Practical implications}

Compiling EPDs for plants and soils would support raising landscape industry to the same level as the building sector, enabling the assessment of the $\mathrm{C}$ impacts and the communication of the environmental performance of the products. EPDs for plants and soils would benefit several stakeholders. For project owners (e.g. municipalities or construction companies), green investments not only support achieving aims for $\mathrm{C}$ neutrality but also market and communicate the values attached to sustainability. For public authorities and designers, an LCA of the landscape design project with the help of EPDs would add transparency to and an understanding of the sustainability of alternative design solutions. The assessment model could be used in several stages in the technical design phase with specifications on materials; and in the concept phase, for comparing alternative options.

The most important phase is that of construction and public procurement, during which an EPD would support the evaluation of the environmental quality of the competing products as well as the making of evidence-based decisions on the sustainability of the landscape design project. For suppliers (nurseries and growing media or mulch suppliers), an EPD would support differentiating between product options and making informed choices. For manufacturers, a demand for EPDs would encourage developing more sustainable products. Finally, users of the green spaces are interested in the climate impact of the parks they use and their own courtyard, which might also affect the value of the property.

Mainstreaming EPDs for plants and soils would also require changes in the processes and sustainability metrics of landscape design and construction. Sustainability standards and environmental classifications are not systematically used in GI design and construction. Therefore, despite its potential benefits, requesting EPDs or conducting LCAs has not been relevant. Mainstreaming EPDs for plants and soils would require developing and applying environmental management and classification systems for landscape design and construction projects on a large scale. This would oblige the project owners to require EPD-based assessment, as well as encourage the manufacturers and suppliers to apply EPD and improve their products. In addition to effective classifications, taking the $\mathrm{C}$ uptake of GI better into account would also imply transdisciplinary approaches and multilevel governance, uniting different actors of the process (Wamsler et al. 2020).

\section{Conclusions}

In this study, we have analysed the adaptability of EPD in the products of landscape design and construction, as well as highlighted some of the key differences of plants, soils, and mulches regarding compiling EPDs for construction products. We argue that green infrastructure should also be considered in low $\mathrm{C}$ construction projects. Therefore, environmental data and EPDs are equally relevant for them. Our study reveals that the main differences to conventional construction products are related to the growth of plants and consequent accumulation of biomass and organic $\mathrm{C}$, as well as reproduction. Furthermore, the inherent $\mathrm{C}$ dynamics of soils as well as the lack of clear end-of-life stage for both soils and mulches set them both apart from most construction products.

We have also identified relevant further research needs. These include developing or adapting models for the growth of plants and $\mathrm{C}$ accumulation in soil, and accounting for and classifying or modeling the differences originating from climate, specific site conditions, and maintenance in landscape $\mathrm{C}$ dynamics. We suggest that relevant standardisation bodies and green building certification developers apply these findings and consider the need to mandate technical committees to work on the topic. Although we have limited our study to only organic products, the role of inorganic and organic fertilisers in $\mathrm{C}$ balance in green infrastructure would deserve similar attention.

The contribution of this study is to initiate a discussion for conducting, compiling, and adapting the required research about the $\mathrm{C}$ dynamics of living and organic products of landscape architecture. With the help of such research, logically sound, accurate, and practically relevant environmental product data could ultimately be compiled for plants, soils, and mulches. If the natural $\mathrm{C}$ sequestration of soils and plants cannot be considered in the current framework, we fall short of quantifying its climate potential in the context of the built environment. Considering the rapidly proceeding climate crisis, all approaches are necessary for mitigating the climate change as well as for establishing regenerative design and construction approaches for a healthy, sustainable, and resilient future.

Funding Open access funding provided by Aalto University. This work was partly supported by Strategic Research Council at the Academy of Finland (CO-CARBON 335201; 335202).

Open Access This article is licensed under a Creative Commons Attribution 4.0 International License, which permits use, sharing, adaptation, distribution and reproduction in any medium or format, as long as you give appropriate credit to the original author(s) and the source, provide a link to the Creative Commons licence, and indicate if changes were made. The images or other third party material in this article are included in the article's Creative Commons licence, unless indicated otherwise in a credit line to the material. If material is not included in 
the article's Creative Commons licence and your intended use is not permitted by statutory regulation or exceeds the permitted use, you will need to obtain permission directly from the copyright holder. To view a copy of this licence, visit http://creativecommons.org/licenses/by/4.0/.

\section{References}

Arzouanidi I, Salomone R, Petti L, Mondello G, Raggi A (2017) Is there a simplified LCA tool suitable for the agri-food industry? An assessment of selected tools. J Clean Prod 149:406-425. https:// doi.org/10.1016/j.jclepro.2017.02.059

Atsbha T (2019) Carbon sequestration potential of natural vegetation under grazing influence in Southern Tigray, Ethiopia: implication for climate change mitigation. Heliyon, 5(8)

Bae J, Ryu Y (2015) Land use and land cover changes explain spatial and temporal variations of the soil organic carbon stocks in a constructed urban park. Landsc Urban Plan 136:57-67

Bastin J-F, Finegold Y, Garcia C, Mollicone D (2019) The global tree restoration potential. Science 365(6448):76-79. https://doi.org/ $10.1126 /$ science.aax 0848

Bianchini F, Hewage K (2012) How "green" are the green roofs? Lifecycle analysis of green roof materials. Build Environ 48:57-65. https://doi.org/10.1016/j.buildenv.2011.08.019

Bringezu S, Schütz H, Pengue W, O’Brien M, Garcia F, Sims R, Herrick J (2014) Assessing Global Land Use: Balancing Consumption with Sustainable Supply. A Report of the Working Group on Land and Soils of the International Resource Panel. UNEP

Brudler SA-N (2016) Life cycle assessment of stormwater management in the context of climate change adaptation. Water Res 106:394-404

CEN European Committee for Standardization (2010) EN 156431:2010 Sustainability of construction works - sustainability assessment of buildings - Part 1: General framework. CEN, Brussels

CEN European Committee for Standardization (2011a) EN 156432:2011 Sustainability of construction works - sustainability assessment of buildings - Framework for the assessment of environmental performance. CEN, Brussels

CEN European Committee for Standardization (2011b) EN 15978. Sustainability of construction works - Assessment of environmental performance of buildings - Calculation method. Brussels: CEN

CEN European Committee for Standardization (2019) EN 15804:2019. Sustainability of construction works. Environmental product declarations. Core rules for the product category of construction products. Brussels: CEN

Chenani S, Lehvävirta S, Häkkinen T (2015) Life cycle assessment of layers of green roofs. J Clean Prod 90:153-162. https://doi.org/ 10.1016/j.jclepro.2014.11.070

Chow P, Rolfe G (1989) Carbon and hydrogen contents of shortrotation biomass of five hardwood species. Wood Fiber Sci 21(1):30-36

Cui S, Borgemenke J, Liu Z, Li Y (2019) Recent advances of "soft" bio-polycarbonate plastics from carbon dioxide and renewable bio-feedstocks via straightforward and innovative routes. J CO2 Util 34:40-52. https://doi.org/10.1016/j.jcou.2019.05.027

Dhakal S (2010) GHG emissions from urbanization and opportunities for urban carbon mitigation. Curr Opin Environ Sustain 2(4):277283. https://doi.org/10.1016/j.cosust.2010.05.007

Dittmeyer R, Klump M, Kant P, Ozin G (2019) Crowd oil not crure oil. Nat Commun 10(1):1-8. https://doi.org/10.1038/ s41467-019-09685-x

Dodd N, Cordella M, Traverso M, Donatello S (2017) Level(s) - A common EU framework of core sustainability indicators for office and residential buildings. Part 3: How to make performance assessments using Level(s). Seville: European Commission, Joint Research Centre

ECORYS (2014) Resource efficiency in the building sector. Rotterdam: DG Environment

Environment Centre of the City of Helsinki (2016) Developing the Helsinki Green Factor Tool: Report summary. Helsinki: Environment Centre

European Commission, Joint Research Centre (2012) Product Environmental Footprint (PEF) Guide. Ispra: JRC.

Friedlingstein P, Jones M, O’Sullivan M, Andrew R, Hauck J, Peters G, Jackson R (2019) Global Carbon Budget 2019. Earth Syst Sci Data 11:1783-1838. https://doi.org/10.5194/essd-11-1783-2019

Grayston S, Vaughan D, Jones D (1997) Rhizosphere carbon flow in trees, in comparison with annual plants: the importance of root exudation and its impact on microbial activity and nutrient availability. Appl Soil Ecol 5(1):29-56

Hari P, Nikinmaa E, Pohja T, Siivola E, Bäck J, Vesala T, Kulmala M (2013) Station for measuring ecosystem-atmosphere relations: SMEAR. Physical and physiological forest ecology. Springer, Dordrecht, pp 471-487

ISO International Organization for Standardization (2010) ISO 14025. Environmental labels and declarations. Type III environmental declarations. Brussels: ISO

IPCC Intergovernmental Panel on Climate Change (2006) IPCC Guidelines for National Greenhouse Gas Inventories. Japan: IGES

IPCC Intergovernmental Panel on Climate Change (2018) Global Warming of $1.5 \mathrm{C}$. : WMO and UNEP

Juhola S (2018) Planning for a green city: The Green Factor tool. Urban for Urban Green 34(August):254-258. https://doi.org/10.1016/j. ufug.2018.07.019

Kalliokoski T, Heinonen T, Holder J, Lehtonen A, Mäkelä A, Minunno F, Kanninen M (2019) Skenaarioanalyysi metsien kehitystä kuvaavien mallien ennusteiden yhtäläisyyksistä ja eroista [A scenario analysis on the similarities and differences of forest models]. Helsinki: Suomen ilmastopaneeli

Keeley M (2011) The Green Area Ratio: an urban site sustainability metric. J Environ Plan Manag 54(7):937-958

Kosareo L, Ries R (2007) Comparative environmental life cycle assessment of green roofs. Build Environ 42(7):2606-2613. https://doi. org/10.1016/j.buildenv.2006.06.019

Koura J, Manneh R, Belarbi R, El Khoury V, El Bachawati M (2020) Comparative cradle to grave environmental life cycle assessment of traditional and extensive vegetative roofs: an application for the Lebanese context. Int J Life Cycle Assess 25:423-442. https://doi. org/10.1007/s11367-019-01700-z

Kuittinen M, Moinel C, Adalgeirsdottir K (2016) Carbon sequestration through urban ecosystem services - A case study from Finland. Sci Total Environ 563-564:623-632. https://doi.org/10.1016/j. scitotenv.2016.03.168

Kuittinen M, Zernicke C, Slabik S, Hafner A (2021) How can carbon be stored in the built environment? A review of potential options. Archit Sci Rev. https://doi.org/10.1080/00038628.2021.1896471

Li C, Frolking S, Frolking T (1992) A model of nitrous oxide evolution from soil driven by rainfall events: 1 . Model structure and sensitivity. J Geophys Res 97(D9):9759-9776

Li X, Zhou Y, Eom J, Yu S, Asrar G (2019) Projecting global urban area growth through 2100 based on historical time series data and future shared socioeconomic pathways. Earths Future 7:351-362. https://doi.org/10.1029/2019EF001152

Lim S, Lee L, Wu T (2016) Sustainability of using composting and vermicomposting technologies for organic solid waste biotransformation: recent overview, greenhouse gases emissions and economic analysis. J Clean Prod 111:262-278

Linden L, Riikonen A, Setälä H, Yli-Pelkonen V (2020) Quantifying carbon stocks in urban parks under cold climate conditions. Urban 
for Urban Green 49:126633. https://doi.org/10.1016/j.ufug.2020. 126633

Liski J, Lehtonen A, Palosuo T, Peltoniemi M, Eggers T, Muukkonen P, Mäkipää R (2006) Carbon accumulation in Finland's forests 1922-2004-an estimate obtained by combination of forest inventory data with modelling of biomass, litter and soil. Ann for Sci 63(7):687-697

Ma S, He F, Tian D, Zou D, Yan Z, Yang Y, Zhou T, Huang K, Shen H, Fang J (2017) Variations and determinants of carbon content in plants: a global synthesis. Biogeosci Discuss 15:693-702

Material Economics (2018) The Circular Economy - a powerful force for climate mitigation. Transformative innovation for prosperous and low-carbon industry. Helsinki: Sitra

McGlashan N, Shaha N, Caldecott B, Workmana M (2012) High-level techno-economic assessment of negative emissions technologies. Process Saf Environ 90(6):501-510. https://doi.org/10.1016/j. psep.2012.10.004

Nowak D, Crane D (2002) Carbon storage and sequestration by urban trees in the USA. Environ Pollut (116)

Nowak D, Crane D, Stevens J, Hoehn R, Walton J, Bond J (2008) A ground-based method of assessing urban forest structure and ecosystem services. Arboric Urban for 34(6):347-358

Pouyat RV, Yesilonis ID, Nowak DJ (2006) Carbon storage by urban soils in the United States. J Environ Qual 35(4):1566-1575

Qian Y, Bandaranayake W, Parton W, Mecham B, Harivandi M, Mosier A (2003) Long-term effects of clipping and nitrogen management in turfgrass on soil organic carbon and nitrogen dynamics. J Environ Qual 32(5):1694-1700

Raciti S, Groffman P, Jenkins J, Pouyat R, Fahey T, Pickett S, Cadenasso M (2011) Accumulation of carbon and nitrogen in residential soils with different land-use histories. Ecosystems 14(2):287-297. https:// doi.org/10.1007/s10021-010-9409-3

Rasinmäki J, Känkänen R (2014) Kuntien hiilitasekartoitus osa 1. Helsingin, Lahden, Turun, Vantaan ja Espoon maankäyttösektorin kasvihuonekaasupäästöt, hiilinielut ja hiilivarastot [Mapping of the carbon balance of municipalities, part 1. Land-use related greenhouse gas emissions, carbon sinks and carbon storages from the cities of Helsinki, Lahti, Turku, Vantaa and Espoo]. Helsingin kaupungin ympäristökeskuksen julkaisuja, 2014(9)

Raum S (2019) Achieving impact from ecosystem assessment and valuation of urban greenspace: The case of i-Tree Eco in Great Britain. Landsc Urban Plan (190)

Regner B, Birkeland J, Midmore D (2014) Net-positive building carbon sequestration. Build Res Inf 43(1):11-24. https://doi.org/10.1080/ 09613218.2015.961001

Renouf M, Renaud-Gentié C, Perrin A, van der Werf H, Kanyarushoki C, Jourjon F (2018) Effectiveness criteria for customised agricultural life cycle assessment tools. J Clean Prod 179:246-254. https://doi.org/10.1016/j.jclepro.2017.12.170

RIBA Royal Institute of British Architects (2013) RIBA Plan of Work, Landscape Architecture

Richter S, Haase D, Thestorf K, Makki M (2020) Carbon pools of Berlin, Germany: organic carbon in soils and aboveground in trees. Urban for Urban Green 54:126777. https://doi.org/10.1016/j.ufug. 2020.126777
Riikonen A, Pumpanen J, Mäki M, Nikinmaa E (2017) High carbon losses from established growing sites delay the carbon sequestration benefits of street tree plantings-a case study in Helsinki, Finland. Urban for Urban Green 26:85-94

Saer A, Lansing S, Davitt NH, Graves RE (2013) Life cycle assessment of a food waste composting system: environmental impact hotspots. J Clean Prod 52:234-244

Sanna A, Uibu M, Caramanna G, Kuusik R, Maroto-Valer M (2014) A review of mineral carbonation technologies to sequester $\mathrm{CO} 2$. Chem Soc Rev 43(2014):8049-8080. https://doi.org/10.1002/chin. 201506312

Setälä H, Francini G, Allen J, Hui N, Jumpponen A, Kotze D (2016) Vegetation type and age drive changes in soil properties, nitrogen and carbon sequestration in urban parks under cold climate. Front Ecol Evol 4:93. https://doi.org/10.3389/fevo.2016.00093

Sier A, Monteith D (2016) The UK Environmental Change Network after twenty years of integrated ecosystem assessment: Key findings and future perspectives. Ecol Indic 68:1-12

Strohbach M, Arnold E, Haase D (2012) The carbon footprint of urban green space-A life cycle approach. Landsc Urban Plan 104(2):220-229. https://doi.org/10.1016/j.landurbplan.2011.10. 013

Säynäjoki E (2015) The untapped potential of urban planning: achieving greater success in environmental sustainability. Aalto University, Helsinki

Thomas S, Martin A (2012) Carbon content of tree tissues: a synthesis. Forests 3(2):332-352. https://doi.org/10.3390/f3020332

Trammell T, Pouyat R, Carreiro M, Yesilonis I (2017) Drivers of soil and tree carbon dynamics in urban residential lawns: a modeling approach. Ecol Appl 27(3):991-1000

UNEP United Nations Environment Programme (2019) Emissions Gap Report. Nairobi: UNEP

USDA Forest Service; Davey Tree Expert Company; The Arbor Day Foundation; Society of Municipal Arborists; International Society of Arboriculture; Casey Trees \& SUNY College of Environmental Science and Forestry (2020) i-Tree. Retrieved 05 26, 2020, from What is i-Tree? https://www.itreetools.org/about

Wamsler C, Wickenberg B, Hanson H, Alkan Olsson J, Stålhammar S, Björn H, Flack H, Gerell D, Oskarsson T, Simonsson E, Torffvit F, Zelmerlow F 2020 Environmental and climate policy integration: Targeted strategies for overcoming barriers to nature-based solutions and climate change adaptation J Clean Prod 247. https:// doi.org/10.1016/j.jclepro.2019.119154

Vasenev V, Kuzyakov Y (2018) Urban soils as hot spots of anthropogenic carbon accumulation: review of stocks, mechanisms and driving factors. Land Degrad Dev 29(6):1607-1622. https://doi. org/10.1002/ldr.2944

Zhang Y, Li C, Zhou X, Berrien M (2002) A simulation model linking crop growth and soil biogeochemistry for sustainable agriculture. Ecol Modell 151(1):75-108

Publisher's Note Springer Nature remains neutral with regard to jurisdictional claims in published maps and institutional affiliations. 